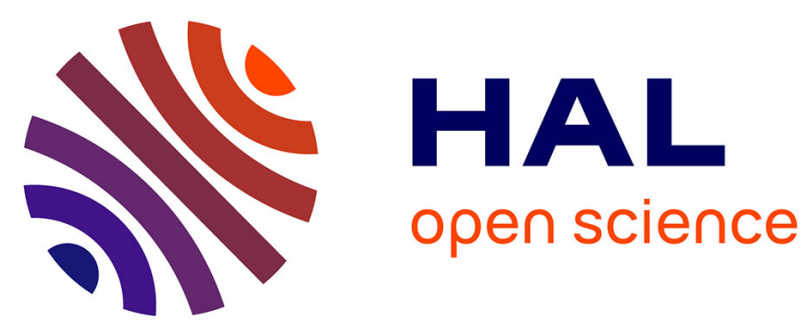

\title{
Areas with high soil percolation by herbicides have higher incidence of low-grade non-Hodgkin lymphomas
}

Rita Fazzi, Chiara Manetti, Daniele Focosi, Lucia Miligi, Alessandra Benvenuti, Enrico Bonari, Roberto Barale, Mario Petrini

\section{To cite this version:}

Rita Fazzi, Chiara Manetti, Daniele Focosi, Lucia Miligi, Alessandra Benvenuti, et al.. Areas with high soil percolation by herbicides have higher incidence of low-grade non-Hodgkin lymphomas. Annals of Hematology, 2010, 89 (9), pp.941-943. 10.1007/s00277-009-0898-0 . hal-00535120

\author{
HAL Id: hal-00535120 \\ https://hal.science/hal-00535120
}

Submitted on 11 Nov 2010

HAL is a multi-disciplinary open access archive for the deposit and dissemination of scientific research documents, whether they are published or not. The documents may come from teaching and research institutions in France or abroad, or from public or private research centers.
L'archive ouverte pluridisciplinaire HAL, est destinée au dépôt et à la diffusion de documents scientifiques de niveau recherche, publiés ou non, émanant des établissements d'enseignement et de recherche français ou étrangers, des laboratoires publics ou privés. 


\title{
Areas with high soil percolation by herbicides have higher incidence of low-grade non-Hodgkin lymphomas
}

\author{
Rita Fazzi • Chiara Manetti • Daniele Focosi • \\ Lucia Miligi - Alessandra Benvenuti - Enrico Bonari • \\ Roberto Barale - Mario Petrini
}

Received: 7 December 2009 /Accepted: 27 December 2009/Published online: 29 January 2010

(C) Springer-Verlag 2010

\section{Dear Editor,}

The incidence rate of non-Hodgkin lymphomas (NHL) doubled over the past two decades in both the US and most westernized countries [1]. Etiology remains largely unknown, but herbicide exposure (especially to phenoxyacids) has been considered a risk factor for indolent NHLs since the 1990s [2-4]. Although the fraction of agricultural workers in westernized countries is small and decreasing over time, herbicide exposure of the general population has been increasing [1]. Despite general population exposures may be lower than those in occupational settings, a relative risk as small as 1.2 could explain $15 \%$ of the current NHL risk, assuming that over $90 \%$ of the general population is exposed [5].

R. Fazzi $(\bowtie) \cdot$ D. Focosi $\cdot$ M. Petrini

Division of Hematology, Department of Oncology,

Transplants and Advances in Medicine, University of Pisa, Pisa, Italy

e-mail: r.fazzi@hotmail.it

\section{Manetti}

Division of Oncology, Azienda Ospedaliera Lucca, Lucca, Italy

\section{Miligi • A. Benvenuti}

Institute for Study and Cancer Prevention, ISPO,

Environmental and Occupational Epidemiology,

Florence, Italy

\section{E. Bonari}

Scuola Superiore di Studi Universitari e Perfezionamento

Sant'Anna,

Pisa, Italy

R. Barale

Division of Genetics, University of Pisa,

Pisa, Italy
Based on preliminary unpublished observations on the geographical clustering of mortality from NHLs in the province of Pisa (western Tuscany, Italy), we ran an ecological study on the distribution of NHL cases in areas with high exposure to herbicides.

We defined exposure to herbicides using an index calculated as follows: the 2,450,000 ha of the province of Pisa were subdivided into geofunctional areas marking autonomous systems characterized by very low intermigration, closed water system, and homogeneous soil composition [6]. Data on spraying of the 13 most used herbicides in the province of Pisa in 1988-1990 were extrapolated from the recordings of the Italian Health Ministry [7], as reported in Table 1. A modification of Mackay and Peterson's model of fugacity was used to calculate herbicide percolation into the soil [8-11]. Land areas treated with herbicides were estimated on the basis of the 1980 Third General Census of Italian Agriculture [12], and herbicide use was assumed homogeneous throughout the whole province. The theoretical concentration of each active ingredient expected in percolation water in 19881990 was estimated as micrograms per gram of soil. Assuming that all active ingredients had the same lymphomagenic impact, a cumulative concentration index $(\mathrm{Cw})$ was used (millimeter per cubic meter).

At first, we retrospectively investigated the correlation between the herbicide soil percolation index in 1988-1990 and mortality from NHLs in the province of Pisa in the period 1987-1992. Overall, 370 deaths from NHLs occurred in the study period. Mortality rates were calculated for each geofunctional area using data obtained from the Tuscan Mortality Registry. Soil percolation by herbicides and mortality rates of NHLs were then correlated using Spearman's rank test $(\rho)$, showing a moderate correlation $(\rho=0.355 ; p<0.05)$. 
Table 1 The 13 most used herbicides in the province of Pisa in 1988-1990

\begin{tabular}{llc}
\hline Herbicide & Month(s) used & Estimated used dose (kg/ha) \\
\hline Alachlor & May & 2.68 \\
2,4-Dichlorophenoxyacetic (2,4-D) & February, March, April & 0.23 \\
2-Methyl-4-chloro-phenoxyacetic (MCPA) sodium & February, March, April & 0.62 \\
Trifluralin & November & 0.54 \\
Atrazine & May & 1.22 \\
Linorun & May & 0.5 \\
Chlortoluron & November & 0.85 \\
Metamitron & February, March, April & 10.1 \\
Glyphosate & February, March, April & 0.13 \\
Chloridazon & February, March, April & 6.7 \\
Methabenzthiazuron & November & 0.92 \\
$S$-ethyl- $N$, $N$-dipropylthiocarbamate (EPTC) & May & 6.4 \\
Diclofop-methyl & February, March, April & 0.52 \\
\hline
\end{tabular}

Since herbicide exposure likely requires some years for a NHL to develop, we designed a new study accounting for a latency time of 10-15 years between exposure and diagnosis of NHLs. We investigated the correlation between soil percolation by herbicides in 1988-1990 and number of new diagnoses of NHLs in 1999-2003 in the province of Pisa. For this study, the incidence rate of NHL was calculated using the electronic medical registries of the Divisions of Hematology and Pathological Anatomy in the province, and International Classification of Diseases (ICD) codes 200 and 202 on discharge forms from the three hospitals in the province of Pisa. This low-level data collection allowed us to subclassify the 381 new NHL cases as low-grade or high-grade according to the REAL classification [13]. Incidence rates were calculated for each geofunctional area as in the former mortality study. Soil percolation by herbicides and incidence of NHLs were again correlated using Spearman's rank test $(\rho)$. The results showed a statistically significant correlation $(\rho=0.53 ; p<$ 0.0005 ) between the standardized incidence rate of NHLs and $\mathrm{Cw}$ index, with most cases reported in areas with $\mathrm{Cw}>$ $12 \mu \mathrm{g} / \mathrm{g}$ and least cases reported in areas with $\mathrm{Cw}<6$. Most importantly, the correlation was observed for low-grade NHLs $(\rho=0.61, p<0.0001)$, but not for high-grade NHLs
Fig. 1 Geographical distribution of $\mathrm{Cw}$ indices (a) and low-grade NHL incidence rates (b) on a simplified provincial map
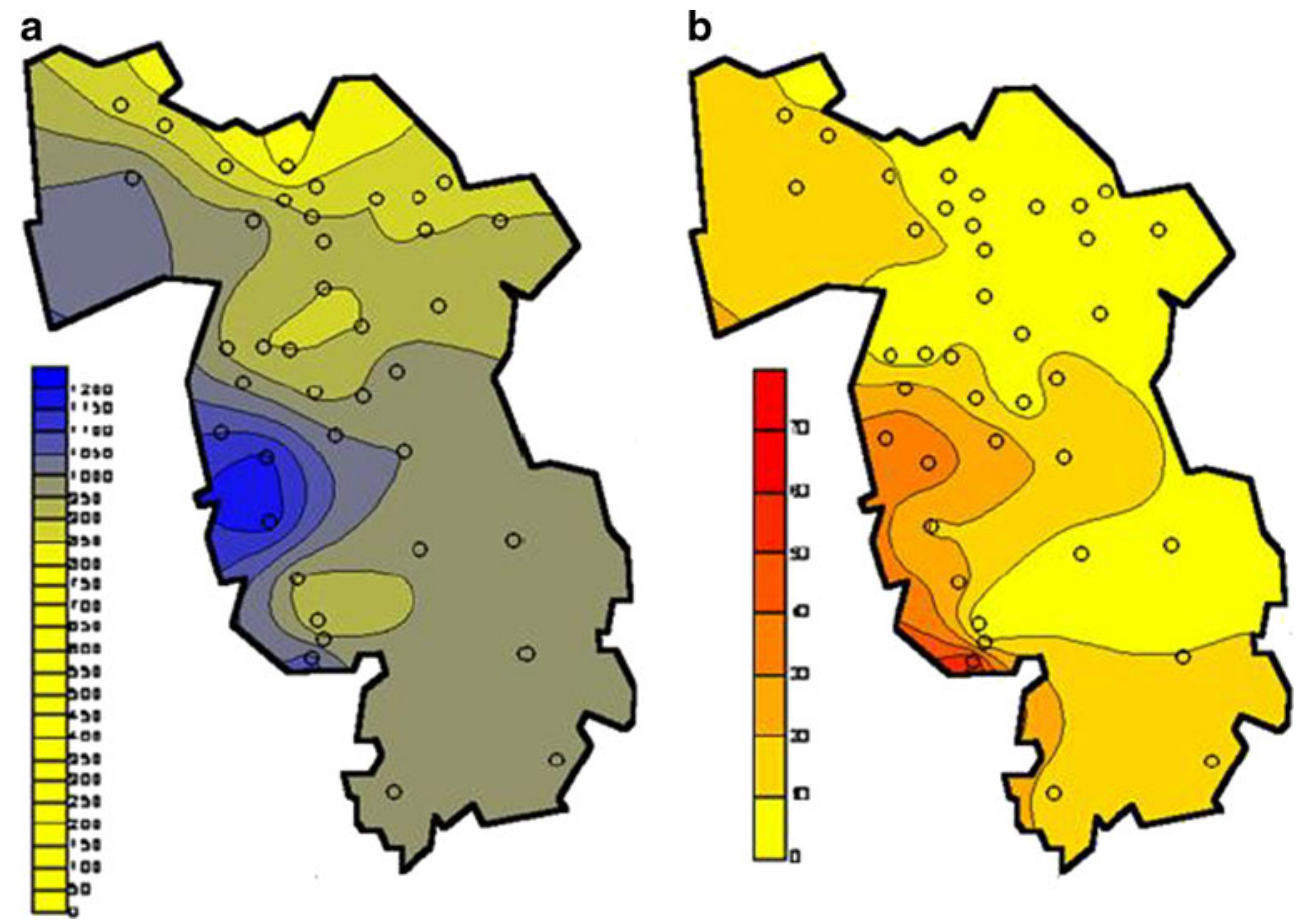
( $\rho=0.14, p=0.40$ ). Maps show the geographical distribution of $\mathrm{Cw}$ index (Fig. 1a) and low-grade NHL incidence rates (Fig. 1b) on a simplified provincial map.

Although studies are ongoing to establish the relative contribution of other potential confounders (such as soil percolation by other kinds of pesticides [14], differential air pollution, occupational exposures, obesity or infectious history) and nevertheless the limits of the ecological study design, the observed results suggest that nonprofessional herbicide exposure (assessed through percolation into the soil) may be a risk factor for low-grade NHLs after a latency time longer than 10 years.

Conflict of interests We declare that we have no conflict of interest related to this manuscript.

\section{References}

1. Fisher SG, Fisher RI (2004) The epidemiology of non-Hodgkin's lymphoma. Oncogene 23(38):6524-6534

2. Cantor K, Blair A, Everett G (1992) Pesticides and other agricoltural risk factors for non-Hodgkin's lyphoma among men in Iowa and Minnesota. Cancer Res 52:2447-2455
3. Zahm S, Weisemburg D, Babbitt P (1990) A case control study of non-Hodgkin's lyphoma and the herbicide 2, 4-dichlorophenoxiacetic acid (2, 4-D) in eastern Nebraska. Epidemiology 1:349-356

4. Delancey J et al (2009) Occupational exposure to metribuzin and the incidence of cancer in the Agricultural Health Study. Ann Epidemiol 19:388-95

5. Rabkin C, MM Ward A, Blattner W (1997) Epidemiology of nonHodgkin's lymphomas. In: Magrath IT (Ed) The Non-Hodgkin's Lymphomas. 2nd ed. Oxford University Press, New York, NY, pp 171-186

6. Bonari E (1993) Coltivazioni erbacee e rischi ambientali in provincia di Pisa. Pisa Centro Studi Economico-Finanziari

7. Catizone P (1991) Diserbo. In: Accademia Nazionale di Agricoltura (Ed) Agricoltura e ambiente. Edagricole Bologna, pp 481-540

8. Mackay D (1979) Finding fugacity feasible. Environ Sci Technol 10:1218-1223

9. Mackay D (2004) Finding fugacity feasible, fruitful, and fun. Environ Toxicol Chem 23(10):2282-2289

10. Mackay D, Paterson S (1982) Calculating fugacity. Environ Sci Technol 15:654-660

11. Mackay D, Paterson S (1982) Fugacity revisited. Environ Sci Technol 15:654-660

12. (ISTAT), I.I.f.S. (1980) Third General Census of Italian Agriculture

13. Harris N, Jaffe ES, Stein H, Banks P (1994) A revised EuropeanAmerican classification of lymphoid neoplasms: a proposal from the International Lymphoma Study Group. Blood 84:1361-1392

14. Colt $J$ et al (2009) Organochlorine exposure, immune gene variation, and risk of non-Hodgkin lymphoma. Blood 113 (9):1899-1905 